\title{
Sidik Jari sebagai Pendukung Alat Bukti dalam Proses Penyidikan Perkara Pidana
}

\author{
Uswantun Hasanah, Yulia Monita \\ Fakultas Hukum, Universitas Jambi \\ Author's Email Correspondence: Uswatun683@gmail.com
}

\begin{abstract}
ABSTRAK
Tujuan penelitian ini adalah untuk mengetahui penggunaan sidik jari bisa mendukung proses pembuktian alat bukti dalam proses penyidikan perkara pidana di Polda Jambi serta untuk mengetahui efektivitas sidik jari sebagai pendukung alat bukti dalam proses penyidikan perkara pidana. Banyaknya kasus kejahatan yang terjadi di Jambi membuat pihak kepolisian semakin meningkatkan kinerjanya yang salah satunya ialah dalam proses penyidikan dengan mencari bukti petunjuk yang salah satunya sidik jari. Hasil penelitian ini adalah penggunaan sidik jari bisa mendukung proses pembuktian alat bukti dalam proses penyidikan perkara pidana, karena dengan ditemukannya sidik jari seseorang yang diduga melakukan tindak pidana maka akan memudahkan pihak kepolisian dalam mencari bukti lain, untuk di Jambi sendiri penggunaan sidik jari sebagai bukti awal jarang dilakukan terlihat dari tahun 20162019 hanya terdapat 5 kasus yang menggunakan sidik jari sebagai petunjuk awal, karena di Jambi sendiri masih memiliki banyak kekurangan seperti pada saat olah TKP banyak ditemukan sidik jari akan tetapi banyak yang sudah rusak, dan banyak kejadian tindak pidana yang tidak langsung dilaporkan, untuk efektivitasnya sendiri Polda Jambi memiliki peralatan yang sangat lengkap dan canggih sudah seperti di Mabes Polri dan sangat efektif dari segi kasus dan alatnya bahwa dari 5 kasus yang terjadi semuanya efektif dengan menggunakan sidik jari sebagai alat bukti petunjuk awal.
\end{abstract}

Kata Kunci: Alat bukti; sidik jari; pembuktian.

\section{LE HISTORY \\ Submission: \\ Accepted: \\ Publish:}

KEYWORDS: Fingerprint, evidence; proof.

\begin{abstract}
The purpose of this study was to determine the use of fingerprints to support the process of proving evidence in the investigation of criminal cases in the Jambi Regional Police and to determine the effectiveness of fingerprints as supporting evidence in the investigation of criminal cases. The number of criminal cases that occurred in Jambi made the police improve their performance, one of which was in the investigation process by looking for evidence of evidence, one of which was a fingerprint. The results of this study are the use of fingerprints can support the process of proving evidence in the investigation of criminal cases, because the discovery of fingerprints of someone suspected of committing a crime will make it easier for the police to find other evidence, for in Jambi itself the use of fingerprints as preliminary evidence rarely seen from 2016-2019, there were only 5 cases that used fingerprints as an initial guide, because in Jambi itself still had many shortcomings such as at the time of the crime scene many fingerprints were found but many were already damaged, and many criminal acts were indirectly reported, for its own effectiveness the Jambi Regional Police have very complete and sophisticated equipment such as those at the National Police Headquarters and are very effective in terms of cases and tools that all 5 cases that occurred were effective using fingerprints as evidence for initial instructions.
\end{abstract}




\section{A. PENDAHULUAN}

Di dalam proses penyidikan, menemukan sebuah kebenaran atas suatu peristiwa yang disebabkan oleh manusia tidaklah mudah, karena sering terjadi kekurangan dan tidak lengkapnya suatu alat bukti ataupun saksi. Sehingga para penyidik harus bekerja lebih keras dalam mengumpulkan alat bukti yang sah untuk mendapat kebenaran yang sebenarnya.

Pada dasarnya, aspek pembuktian ini sebenarnya sudah dimulai pada tahap penyelidikan perkara pidana. Dalam tahap penyelidikan, tindakan penyelidikan dilakukan untuk mencari dan menemukan suatu peristiwa yang diduga sebagai tindak pidana guna dapat atau tidaknya dilakukan penyidikan, sementara dalam tahapan ini sudah ada tahapan pembuktian. Begitu pula halnya dengan ditentukan adanya tindakan penyidik untuk mencari serta mengumpulkan bukti dan dengan bukti tersebut membuat terang tindak pidana yang terjadi dan guna menemukan tersangkanya.

Cara mempergunakan dan menilai kekuatan pembuktian yang melekat pada setiap alat bukti dilakukan dalam batas-batas yang dibenarkan undang-undang, agar dalam mewujudkan kebenaran yang hendak dijatuhkan, majelis hakim terhindar dari pengorbanan kebenaran yang harus dibenarkan. Jangan sampai kebenaran yang diwujudkan dalam putusan, berdasarkan hasil perolehan dan penjabaran, keluar dari garis yang dibenarkan sistem pembuktian. ${ }^{1}$

Di dalam pemeriksaan persidangan perkara pidana hakim yang melakukan pemeriksaan persidangan namun tanpa adanya alat bukti, hakim tidak akan dapat mengetahui dan memahami apakah suatu tindak pidana telah terjadi dan apakah terdakwa telah benar-benar melakukan tindak pidana tersebut dan bertanggung jawab atas peristiwa itu, jadi adanya alat bukti mutlak diperlukan sehingga hakim dapat dengan pasti menemukan kebenaran materil.2

Berdasarkan Pasal 183 Undang-Undang Nomor 8 Tahun 1981 Tentang Kitab Undang-undang Hukum Acara Pidana (KUHAP) dapat disimpulkan bahwa:

Seorang hakim dalam hal menjatuhkan pidana kepada terdakwa tidak boleh menjatuhkan pidana tersebut kecuali apabila dengan sekurang-kurangnya 2 (dua) alat bukti yang sah, sehingga hakim memperoleh keyakinan bahwa suatu tindak pidana benar-benar terjadi dan terdakwalah yang bersalah melakukannya (Pasal 183 KUHAP). Alat bukti sah yang dimaksud adalah keterangan saksi, keterangan ahli, surat, petunjuk, keterangan terdakwa atau hal yang secara umum sudah diketahui sehingga tidak perlu dibuktikan (Pasal184KUHAP). ${ }^{3}$

1 Sahuri Lasmadi, "Pengaturan Alat Bukti Dalam Tindak Pidana Dunia Maya", Jurnal IImHukum Jambi, Vol. 5, 2014, hlm. 8. https://www.neliti.com/publications/43274/pengaturan-alat-buktidalam-tindakpidanadunia maya\#cite

2 Yulia Monita, Dheni Wahyudhi "Peranan Dokter Forensik Dalam Pembuktian Perkara Pidana",Jurnal IImu Hukum,Vol 6, 2013, hlm. 128.

https://scholar.google.co.id/citations?user=878U4XEAAAAJ\&hl=id\#d=gs_md_citad\&u=\%2Fcitatio ns\%3Fview_op\%3Dview_citation\%26hl\%3Did\%26user\%3D878U4XEAAAAJ\%26citation_for_view \%3D878U4XEAAAAJ\%3Au5HHmVD_uO8C\%26tzom\%3D-420

3 Meli Indah Sari, \& Hafrida, H. (2020). Penerapan Pidana Penjara Sebagai Pengganti Pidana Denda dalam Putusan Perkara Tindak Pidana Narkotika. PAMPAS: Journal of Criminal Law, 1(1), 38-53. Retrieved from https://www.online-journal.unja.ac.id/Pampas/article/view/8260, hlm. 41. 
Untuk dapat ditemukannya bukti-bukti tersebut maka terlebih dahulu dilakukan tahap penyelidikan yaitu serangkaian tindakan penyelidik untuk mencari dan menemukan suatu peristiwa yang diduga sebagai tindak pidana guna menentukan dapat atau tidaknya dilakukan penyidikan menurut cara yang diatur dalam undang undang. 4

Seiring dengan perkembangan zaman peralatan canggih yang bisa membantu manusia dalam menyelesaikan suatu pekerjaan, maka semakin muda pula seseorang dalam melaksanakan tugas nya, begitu juga dengan "seorang polisi dalam mengungkap suatu kejahatan, maka muncul gagasan ke arah polisi profesional yang mutakhir dan bertolak dari keinginan untuk melakukan perombakan sesuai dengan perkembangan ilmu pengetahuan dan teknologi yang cepat."5 Pada proses penyidikan akan dilakukan melalui beberapa proses yang salah satunya yakni dengan mengambil sidik jari. Adanya ilmu tentang identifikasi sidik jari pada dasarnya memudahkan pihak Kepolisian untuk mengungkap suatu kasus perkara pidana. Setiap proses identifikasi di tempat kejadian perkara untuk mengetahui sidik jari korban maupun tersangka, harus sesuai dengan standar operasional prosedur (SOP) yang wajib dijalankan. Sidik jari yang merupakan salah satu ciri yang dimiliki seseorang, sidik jari setiap orang tidak akan pernah sama dan tidak akan tertukar. Bentuk dan polanya berbeda beda. Ini berarti sidik jari bisa dikatakan sebagai identitas seseorang, dengan ditemukan nya metode menggunakan sidik jari maka bisa digunakan untuk mengidentifikasi dan mengungkap kasus pidana, baik itu terhadap korban maupun tersangka.

“Korban disini adalah mereka yang menderita jasmani dan rohaninya sebagai akibat tindakan orang lain yang bertentangan dengan kepentingan diri sendiri atau orang lain yang mencari pemenuhan kepentingan diri sendiri atau orang lain yang bertentangan dengan kepentingan hak asasi yang menderita."6

"Sidik jari bisa dikategorikan sebagai alat bukti di dalam identifikasi, sidik jari merupakan dactylosscopy yang berarti merupakan ilmu yang mempelajari sidik jari untuk keperluan pengenalan kembali identitas orang dengan cara mengamati garis yang terdapat pada guratan garis jari tangan dan telapak kaki."7

Pemanfaatan peran sidik jari dalam mengungkap pelaku kejahatan merupakan langkah strategis yang mungkin dilakukan saat ini, mengingat keotentikan alat bukti sidik jari itu sendiri yang dinilai sangat akurat, sebagaimana diatur dalam Kitab Undang-undang Hukum Acara Pidana Pasal 7 huruf f tentang kewenangan penyidik untuk mengambil sidik jari dan memotret seorang, Undang-Undang Kepolisian Nomor 22 Tahun 2002 Pasal 15 Ayat (1) huruf h yang menyebutkan bahwa: "yang berwenang mengambil sidik jari dan memotret seseorang adalah pihak kepolisian"

4 Andi Muhammad Sofyan dan Abd. Asis, Hukum Acara Pidana Suatu Pengantar, Kencana, Jakarta, 2014, hlm. 82

5 Kabib Nawawi, "Progresifitas Polisi Menuju Polisi Profesional", Inovatif Jurnal Ilmu Hukum, Vol. 2, Tahun 2010, HIm. 57. https://online-journal.unja.ac.id/index.php/jimih/article/view/202

6 Hafrida, "Kebijakan Hukum Pidana terhadap Pengguna Narkotika sebagai Korban Bukan Pelaku Tindak Pidana: Studi Lapangan Daerah Jambi," Padjadjaran Journal Of Law, Vol 1 no. 3, 2016, $\mathrm{HIm}$. 188. https://scholar.google.co.id/citations?user=xT8MpbIAAAAJ\&hl=id\#d=gs_md_cita$\mathrm{d} \& \mathrm{u}=\% 2$ Fcitations\%3Fview_op\%3Dview_citation\%26hl\%3Did\%26user\%3DxT8MpbIAAAAJ\%26cit ation_for_view\%3DxT8MpbIAAAAJ\%3AM3NEmzRMIkIC\%26tzom\%3D-420

7 https://id.wikipedia.org/wiki/Sidik_jari, diakses pada hari Jumat tanggal 25 oktober, pukul 11.11 WIB. 
Dari alat-alat bukti yang tercantum dalam Pasal 184 KUHAP, maka sidik jari bisa masuk dalam kategori alat bukti surat maupun petunjuk. Sebagai alat bukti surat dan petunjuk, tentunya berdampak sangat signifikan dalam mengungkap kasus-kasus pidana.

Sidik jari sebagai alat bukti surat. Berkenan dengan alat bukti surat diatur dalam Pasal 187 KUHAP, sebagai berikut:

a. Berita acara dan surat lain dalam bentuk resmi yang dibuat oleh pejabat umum yang berwenang atau yang dibuat di hadapannya yang memuat keterangan tentang kejadian atau keadaan yang didengar, dilihat atau yang dialaminya sendiri, disertai dengan alasan yang jelas dan tegas tentang keterangan itu;

b. Surat yang dibuat menurut ketentuan peraturan perundang- undangan atau surat yang dibuat oleh pejabat mengenai hal yang termasuk dalam tatalaksana yang menjadi tanggung-jawabnya dan yang diperuntukkan bagi pembuktian sesuatu hal atau sesuatu keadaan;

c. Surat keterangan dari seorang ahli yang memuat pendapat berdasarkan keahliannya mengenai sesuatu hal yang atau sesuatu keadaan yang diminta secara resmi dari padanya;

d. Surat lain yang hanya berlaku jika ada hubungannya dengan isi dari alat pembuktian yang lain.

Dari isi Pasal 187 KUHAP di atas, maka sidik jari termasuk dalam kategori Pasal 187 huruf c dan d. Karena sidik jari itu dianalisis oleh seorang yang ahli sidik jari dan kemudian hasil analisisnya dituangkan dalam bentuk 'surat'.

Sidik jari sebagai alat bukti petunjuk. Mengenai petunjuk sebagai alat bukti diatur dalam Pasal 188 KUHAP, sebagai berikut:

Petunjuk adalah perbuatan, kejadian atau keadaan yang karena persesuaiannya, baik antara yang satu dengan yang lain, maupun dengan tindak pidana itu sendiri, menandakan bahwa telah terjadi sesuatu tindak pidana dan siapa pelakunya.

Petunjuk sebagaimana dimaksud dalam Ayat (1), hanya dapat diperoleh dari : keterangan saksi, surat, keterangan terdakwa.

Penilaian atas kekuatan pembuktian dari suatu petunjuk dalam setiap keadaan tertentu dilakukan oleh hakim dengan arif dan bijaksana setelah ia mengadakan pemeriksaan dengan penuh kecermatan dan keseksamaan berdasarkan hati nuraninya.

Sebagaimana isi Pasal 188 KUHAP maka sidik jari jelas sekali tergolong sebagai alat bukti petunjuk. Karena sidik jari dari pelaku yang terdapat pada alat yang digunakan untuk melakukan tindak pidana sudah merupakan suatu bukti yang akurat tentang siapa yang menjadi pelakunya. Sidik jari merupakan alat bukti yang akurat untuk menentukan identitas seseorang secara alamiah.

Tabel di bawah merupakan data kasus perkara pidana yang terjadi dari tahun 2016 hingga 2019, terlihat dari tabel di atas bahwa jumlah kasus yang masuk pada tahun 2016 adalah sebanyak 1086 kasus, dan yang selesai hanya 536 kasus, sisanya ada yang belum di proses ada pula yang masih dalam proses penyidikan, lalu pada tahun 2017 perkara pidana yang terjadi sebanyak 1150 dan yang selesai sebanyak 838, jumlah kasus yang selesai ini tidak menggunakan sidik jari sebagai pembuktian awalnya, karena adanya saksi mata yang melihat langsung dan segera melapor pada pihak kepolisian. 
Tabel 1

Jumlah Tindak Pidana Pencurian dan Pembunuhan yang Terjadi Dari Tahun 2016-2019

\begin{tabular}{llll} 
Tahun & L & S & $\begin{array}{l}\text { Sidik Jari } \\
\text { Bukti } \\
\text { Awal }\end{array}$ \\
\hline 2016 & 1086 & 536 & - \\
\hline 2017 & 1150 & 838 & - \\
\hline 2018 & 1322 & 767 & 2 \\
\hline 2019 & 1012 & 432 & 3
\end{tabular}

Sumber: Polda Jambi tahun 2016-2019

Ket. L= Jumlah kasus masuk.

$\mathrm{S}=$ Jumlah kasus selesai.

lalu pada tahun 2018 terjadi sebanyak 1322 kasus dan yang selesai sebanyak 767 kasus, pada tahun 2018 ada 2 kasus yang menggunakan sidik jari sebagai pembuktian awal yaitu kasus pembunuhan kemudian pada tahun 2019 terjadi 1012 kasus dan yang selesai hanya 432 kasus, pada tahun 2019 ini terdapat 3 kasus pidana yang ditemukan menggunakan sidik jari sebagai pembuktian awal, kasus pidana itu merupakan 1 kasus pencurian dan 2 kasus pembunuhan.

Berdasarkan data di atas rata-rata kasus pidana yang terjadi kebanyakan adalah pencurian dan pembunuhan, akan tetapi yang lebih mendominasi adalah pembunuhan. Dan disini penulis ingin mencari tahu kenapa dengan banyaknya kasus pidana yang terjadi di Jambi ini akan tetapi yang menggunakan sidik jari sebagai bukti awal sangat sulit sekali, dari peran kepolisian yang belum optimal dalam bertugas atau ada faktorfaktor lain yang menyebabkan sidik jari untuk di Jambi ini tidak efektif.

\section{B. METODE PENELITIAN}

Penelitian ini merupakan penelitian yuridis empiris artinya menganalisis permasalahan dengan cara memadukan bahan-bahan hukum (yang merupakan data sekunder) dengan data primer yang diperolah di lapangan.

\section{PEMBAHASAN}

\section{Penggunaan Sidik Jari Sebagai Pendukung Proses Pembuktian Alat Bukti \\ Dalam Penyidikan Perkara Pidana di Polda Jambi}

Berbagai macam kasus pidana yang terjadi tentunya pasti meninggalkan cerita bagaimana kasus tersebut bisa terjadi dan bagaimana pula proses penyidikannya, berdasarkan hasil penelitian penulis ditemukanlah sebuah kasus tindak pidana pencurian yang terjadi di salah satu tempat di daerah Jambi, yang mana tindak pidana tersebut merukapan tindak pidana pencurian dengan pemberatan, karena tindak pidana tersebut dilakukan pada malam hari di sebuah rumah dan dengan kekerasan, sesuai dengan Pasal 365 Ayat (1):

Diancam dengan pidana penjara paling lama sembilan tahun pencurian yang didahului, disertai atau diikuti dengan kekeran atau ancaman kekerasan, terhadap orang dengan maksud untuk mempersiapkan atau mempermudah pencurian, atau dalam hal tertangkap tangan untuk memungkinkan melarikan diri sendiri atau peserta lainnya, atau untuk menguasai barang yang dicuri. 
Pencurian tersebut terjadi pada malam hari dan disebuah rumah, pelaku itu hendak mengambil motor yang sedang terparkir dihalaman rumah, akan tetapi pada saat akan melancarkan aksinya pelaku dipergoki oleh seseorang, dan saat pelaku tahu aksinya dipergoki maka pelaku langsung mengeluarkan pisau dari kantong celananya, dan mengancam orang tersebut, tetapi pelaku berhasil membawa kabur motor tersebut, dan orang yang melihat aksi pelaku langsung memberitahu si pemilik motor tersebut, setelah itu pemilik motor tersebut segera melapor ke Polsek Kota Baru, setelah dilakukan penyidikan oleh pihak kepolisan maka ditemukan sebuah bekas sidik jari yang menempel pada pagar rumah, segera pihak identifikasi mengambil dan merumuskan sidik jari tersebut, dan ternyata pelaku pencurian motor tersebut merupakan residivis, segeralah pihak kepolisian mencari pelaku tersebut, saat pelaku sudah ditemukan pelaku tidak mau mengaku dengan tindak pidana yang sudah ia lakukan, padahal sudah jelas sidik jari yang ada pada pagar rumah tersebut milik pelaku tersebut, tetapi pelaku terus mengelak, untuk saat ini pelaku sudah ditahan di Polsek Kota Baru, akan tetapi belum di proses karena masih p19, karena pihak kepolisian masih terus mencari bukti lain, karena tidak bisa hanya dengan 1 bukti saja yaitu bukti petunjuk sidik jari, walaupun jelas sebenarnya sidik jari pelaku dan sidik jari yang ada pada pagar rumah tersebut jelas milik pelaku ditambah lagi pelaku merupakan residivis. Dari kasus ini terlihat jelas bagaimana peran sidik jari, yang memudahkan pihak kepolisian dalam mencari pelaku tindak pidana.

Berdasarkan berkas perkara nomor BP/38/VIII/2008/Reskrim telah terjadi perkara pidana tanggal 6 Juli 2018 di Kelurahan Legok Kecamatan Danau Sipin Jambi, kejadian berawal pada hari Jumat sekitar pukul 06.00 WIB, saat itu terdakwa berbicara pada korban di dalam kamar korban, saat itu korban menyampaikan pada terdakwa bahwa adik terdakwa menikah dengan orang lain, sementara yang mengambil kehormatan adik terdakwa adalah si korban, mendengar perkataan korban, maka terdakwa emosi dan pada saat korban berbaring di atas kasur dengan posisi tengkurap, lalu terdakwa langsung mengambil satu bilah golok di atas lemari yang ada di kamar korban, melihat terdakwa mengambil golok tersebut, maka korban langsung berdiri dan berteriak dengan mengatakan "WOI" lalu terdakwa berusaha menusukan golok tersebut ke bagian tubuh korban, namun korban berusaha menangkisnya, kemudian terdakwa kembali menikam golok tersebut ketubuh korban dan mengenai perut korban, lalu korban terjatuh bersimbah darah dan kejang-kejang, terdakwa pun langsung melarikan diri, karena perbuatan terdakwa tersebut korban meninggal dunia didukung dengan hasil visum et refertum dari Rumkit Tk. IV dr. Bratanata Jambi Nomor: VIS 01/MED/VII/2018 tanggal 17 Juli 2018, terdakwa ditangkap polisi di kediamannya dengan barang bukti sebuah golok yang digunakan terdakwa untuk melakukan aksinya dan digolok tersebut terdapat sidik jari terdakwa, untuk lebih meyakinkan, maka sidik jari yang ada di golok tersebut disamakan dengan sidik jari terdakwa dan ternyata hasilnya sama, maka dari itu terdakwa langsung ditahan oleh polisi dan dengan adanya 2 orang saksi juga pada saat di TKP.

Berkas perkara nomor BP/70/V/2019/Reskrim bahwa berdasar berkas perkara tersebut telah terjadi tindak pidana pembunuhan pada hari Sabtu 25 Mei 2019 pu kul 19.00 WIB bertempat di rumah kontrakan Desa Pulau Pandan RT.30 Kelurahan Legok Kecamatan Danau Sipin Kota Jambi, terdakwa mulanya bertemu dengan korban di rumah kontrakan tersebut, yang mana pada saat itu terdakwa menawarkan cat besi 
pada korban, sekitar pukul 16.00 WIB, pada saat terdakwa sedang main ikan hias di rumah Anang yang terletak di Pulau Pandan RT.30, korban menjumpai terdakwa dan mengatakan "Sudah Jum, mano catnyo, bawalah! Ado yang mau beli! Bawa kesini biar aku bawa barangnyo!" dan dijawab terdakwa "kageklah dulu, jangan sekarang, malu diliat tetangga" dan saat itu terdakwa langsung pulang ke rumah untuk mengambil cat besi tersebut namun ternyata cat besi tersebut sudah diambil oleh adik terdakwa, selanjutnya terdakwa langsung menemui korban di rumah IR dan terdakwa berkata "bang dak jadi catnyo sudah di ambil adik aku" kemudian korban menjawab "kau ni macam mana? Lolo kau ni! Kau kulunjaki jugo kagek, bengak nian kau ni, akulah cari pembeli, sudah kau ambek be catnyo! Kau tunggu disini!", lalu korban pergi ke arah jembatan yang menghubungkan ke pasar angso duo Jambi, melihat korban pergi terdakwa langsung pulang ke rumah untuk mengambil sebilah pisau dan terdaka simpan di pinggang sebelah kanan, sekitar pukul 19.00 WIB terdakwa kembali lagi ke rumah kontrakan tersebut sambil membawa pisau yang terdakwa simpan di pinggang sebelah kanan, saat melihat korban bersama dengan saksi Alex sedang berbincangbincang dan saat itu pula terdakwa langsung memukul korban dengan menggunakan tangan kanan sebanyak satu kali. Kemudian korban langsung berdiri dan terdakwa langsung mencabut pisau yang telah dipersiapkan terlebih dahulu dan menusukan kearah pinggang kiri korban dan terdakwa terus mengayunkan pisau tersebut kearah korban hingga mengenai tangan kanan dan kiri korban dan terakhir terdakwa menikam pisau tersebut ke arah punggung sebelah kiri korban. Bahwa akibat perbuatan terdakwa korban meninggal dunia berdasar kutipan akta kematian tanggal 19 Juni 2019 No.1571-KM-1806201-0005 dari Dinas Kependudukan Kota Jambi dan diterangkan Surat Visum Et Repertum No:VIS 01/MED/V/2019 Tanggal 25 Mei 2019 ditandatangani oleh dr. Alpasca Firdaus, terdakwa di tangkap polisi dengan barang bukti berupa satu bilah pisau bergagang kayu warna coklat yang mana pada gagang pisau tersebut terdapat sebuah sidik jari, lalu sidik jari tersebut dicocokan dengan sidik jari terdakwa dan ternyata hasilnya cocok dan dengan adanya saksi mata saat di TKP maka terdakwa ditangkap oleh polisi berdasarkan surat penangkapan nomor: sp.kap/92/V/2019/reskrim tanggal 27 Mei 2019.

Seperti yang kita ketahui pada bab sebelumnya macam-macam alat bukti berdasarkan Pasal 184 Kitab Undang-undang Hukum Acara Pidana ialah, Keterangan saksi, Keterangan ahli, Surat, Petunjuk, dan Keterangan terdakwa. Dan sidik jari sendiri merupakan alat bukti petunjuk sesuai dengan Pasal 188 KUHAP, dikarenakan adanya bekas sidik jari pada suatu benda itu sudah menandakan bahwa telah terjadi suatu tindak pidana.

Sebelum masuk kepada bagaimana penggunaan sidik jari bisa mendukung proses pembuktian alat bukti, kita perlu mengetahu bahwa pada saat penyidikan berlangsung, maka penyidikan tersebut bisa saja tiba-tiba dihentikan apabila tidak cukup bukti atau bukti tersebut tidak kuat apakah penyidikan bisa tetap dilanjutkan, berdasarkan pasal 109 Ayat (2) KUHAP apabila penyidik tidak mempunyai bukti yang cukup, maka penyidik harus menghentikan penyidikan, alasan bisa dilakukan penghentian penyidikan apabila tidak terdapat cukup bukti, peristiwa yang disidik oleh penyidik ternyata bukan tindak pidana, penyidikan dihentikan demi hukum alasan dihentikan demi hukum yaitu karena nebis in idem, tersangka meninggal dunia dan suatu perkara tersebut telah kadaluarsa atau lewat masa tenggang 
Lalu bagaimana bisa penggunaan sidik jari bisa mendukung proses pembuktian alat bukti, menurut wawancara yang dilakukan pada Kanit Ditreskrimum Polda Jambi Bapak Ibrahim beliau mengatakan

Sidik jari bisa mendukung proses pembuktian dengan diambil sidik jari oleh bagian identifikasi sidik jari, maka akan diketahui siapa pemilik identitas sidik jari tersebut, kemudian yang bisa menjadi saksi ahli adalah orang yang sudah memiliki sertifikasi, apabila tidak memiliki sertifikasi maka tidak bisa menjadi saksi ahli. ${ }^{8}$

Kemudian Bapak Ibrahim menambahkan, pada saat sudah ditemukan nya bekas sidik jari itu, maka harus dibedakan dulu apakah itu sidik jari latent atau sidik jari nyata, sehingga bisa dipersiapkan alat-alat untuk melakukan pemeriksaan.

Alat utama dan alat khusus daktiloskopi antara lain:

1. Kamera, fungsi kamera disini sangat penting untuk melakukan pemotretan terhadap bekas sidik jari.

2. Sarung tangan, berguna agar terhindar dari bahan kimia yang digunakan untuk pemeriksaan sidik jari serta untuk mencegah agar tidak ada penambahan sidik jari pada benda dimana sidik jari melekat.

3. Tas koper, untuk membawa alat-alat dan bahan yang digunakan untuk pengembangan sidik jari di TKP, bahan-bahan tersebut seperti kuas serbuk biasa, kuas filler glass tangkai alumunium, kuas magnet, meteran, finger print into, sendok mayat, serbuk hitam, serbuk abu-abu, serbuk magnet hitam, serbuk magnet abu-abu, penggiling tinta dari karet, alat penjepit, gunting, nomor, masker, alat tulis, kaca pembesar, kantong barang bukti, kartu sidik jari AK-23, alat untuk mendeteksi sidik jari jari latent.

Alat-alat di atas sangat efektif sekali penggunaannya dalam mengidentifikasi seseorang, bila didukung dengan mendapat bekas-bekas sidik jari yang ditinggalkan di TKP tanpa disentuh ataupun terhapus oleh siapapun, oleh karena itu bekas sidik jari yang terdapat di TKP harus segera di amankan sehingga memudahkan dalam pengambilan bekas sidik jari tersebut untuk dilakukan pemeriksaan forensik.

Lalu menurut wawancara yang dilakukan pada tim Identifikasi sidik jari Polda Jambi Bapak Muzammil,

Untuk penggunaan sidik jari ini sendiri nanti dicari pembandingnya apabila sudah ditemukan pelakunya sudah ditangkap, maka yang mengambil sidik jari tadi dijadikan saksi ahli, jadi memang yang sudah memiliki sertifikasi yang bisa menjadi saksi ahli, dan dibagian identifikasi Polda Jambi ini sendiri sudah ada 4 orang yang memiliki sertifikasi yang memang sudah diakui. ${ }^{9}$

Lebih lanjut lagi menurut wawancara dengan Ibrahim,

Untuk di Polda sendiri pengungkapan melalui sidik jari ini jarang ada dan hampir tidak ada, beliau sudah 4 kali menjadi Kanit mulai dari Polsek, Polresta sampi beliau di Polda ini sendiri memang belum pernah ada kasus yang terungkap hanya dengan menggunakan sidik jari, karena memang sidik jari ini kan fungsinya hanya bukti pendukung petunjuk awal, setelah ditemukan sidik jari maka akan dilakukan pencarian bukti lainnya, dan memang untuk di Polda sendiri lebih kepada membackup, jadi memang untuk kasus-kasus pidana yang

8 Wawancara dengan Ibrahim, Kanit Ditreskrimum Polda Jambi, Tanggal 16 Januari 2020, Pukul 09.00 WIB

9 Wawancara dengan Muzammil, Tim Identifikasi Sidik Jari Polda Jambi, Tanggal 16 Januari 2020, Pukul 09.00 WIB 
terjadi lebih banyak di polsek ataupun polres, apabila mereka meminta bantuan Polda barulah dari tim Polda Jambi turun. ${ }^{10}$

Penggunaan sidik jari ini sendiri sangat bisa mendukung suatu proses pembuktian alat bukti, dikarenakan sidik jari ini pembuktiannya sangat akurat karena sidik jari setiap orang itu tidak ada yang sama. Dalam sistem pembuktian pengaruh sidik jari sangat besar sekali dibanding dengan alat bukti lainnya, hal ini berdasarkan asas sidik jari, yaitu:

a. Menurut penyelidikan, bentuk-bentuk teraan jari itu telah terjadi sejak bayi dalam kandungan (janin) berumur 4 bulan dan akan terus berkembang dari lahir hingga mati. Dalam keadaan matipun bentuk-bentuk teraan sidik jari itu masih tetap terlihat, kecuali jika lapisan kulit itu sudah rusak hancur. Hal ini misalnya dapat terlihat pada mumi-mumi yang dibalsam.

b. Tidak ada satu atau dua orang pun yang berlainan yang mempunyai bentuk-bentuk teraan jari yang sama. Karena susunan dan letak-letak garis teraan jari sedemikian rupa keadaannya dan berbeda-beda antara yang satu dengan yang lain, maka sampai sekarangpun tidak ada ketentuan adanya dua jari yang mempunyai bentuk dan susunan garis yang sama, dalam hal juga pada orang-orang kembar yang sama dalam segala halnya tidak pernah ditemukan yang mempunyai teraan yang sama. 11

c. Sidik jari berkaitan erat dengan bukti permulaan, yaitu sebagai keterangan saksi ahli. Sidik jari latent yang terdapat di TKP harus dibuatkan berita acara pengangkatan sidik jari latent dan hasil dari pemeriksaan sidik jari latent harus dibuat berita acara pemeriksaan sidik jari latent yang dibuat berdasar pendapat ahli. ${ }^{12}$

Peran sidik jari sangat erat kaitannya dengan bukti awal, Keterkaitan antara sidik jari dengan barang bukti adalah secara tidak langsung, sesuai dengan Pasal 39 KUHAP barang bukti itu:

a. Benda yang diperoleh dari hasil tindak pidana;

b. Benda yang digunakan secara langsung untuk melakukan tindak pidana;

c. Benda yang digunakan untuk menghalang-halangi penyidikan pidana;

d. Benda yang khusus dibuat untuk melakukan tindak pidana.

Lalu menurut wawancara dengan Ibrahim beliau mengatakan bahwa:

Pada setiap kasus itu walaupun sudah kuat dengan sidik jari, tetap saksi pendukung itu harus ada, saksi ahli juga harus ada, seperti pada kasus yang pernah diungkap Polda Jambi berapa tahun yang lalu di rumah sekda, itu sudah jelas bahwa ada bekas sidik jari pada kotak perhiasan, dan sudah diambil sidik

10 Wawancara dengan Ibrahim, Kanit Identifikasi Sidik Jari Polda Jambi, Tanggal 16 Januari 2020, Pukul 09.00 WIB.

11 Subaidi, "Keabsahan Sidik Jari Sebagai Alat Bukti Dalam Tindak Pidana Perspektif Hukum", Cendekia Jurnal Studi Keislaman, Vol. 2, No. 2, Tahun 2018, hlm.4, http://ejurnal.staiha.ac.id/index.php/cendekia/article/view/31

12 Made Gede Artadana, "Peran Sidik Jari dalam Mengungkap Pelaku Tindak Pidana di Tingkat Penyelidikan Polda Bali", Jurnal Magister Hukum Udayana, Vol. 4, No. 4, Tahun 2015. Made Gede Arthadana, "Peran Sidik Jari Dalam Mengungkap Pelaku Tindak Pidana Di Polda Bali", Jurnal Magister Hukum Udayana (Udayana Master Law Journal), [S.I.], v. 4, n. 4, dec. 2015. ISSN 2502 3101.https://ojs.unud.ac.id/index.php/jmhu/article/view/18749 
jari nya itu sudah sangat jelas sekali padahal, akan tetapi tetap barang bukti yang lain harus dicari, karena bukti itu tidak bisa hanya satu saja. ${ }^{13}$

Karena sesuai dengan Pasal 183 KUHAP bahwa seorang hakim tidak boleh menjatuhkan pidana kepada seseorang kecuali apabila dengan sekurang-kurangnya dua alat bukti yang sah ia peroleh keyakinan bahwa suatu tindak pidana benar-benar terjadi dan bahwa terdakwalah yang bersalah melakukannya, jadi sudah jelas biarpun kekuatan pembuktian sidik jari itu sangat kuat tapi tetap harus dicari bukti pendukung lainnya.

Menurut Muzammil, bahwa setiap perkara pidana yang terjadi pasti diambil sidik jarinya. "Setiap terjadi tindak pidana pasti diambil sidik jari, lalu disimpan kenapa begitu karena, apabila terjadi lagi perbuatan yang mengulangi maka tinggal membuka AK-23."14

AK-23 ini sendiri merupakan kartu yang menyimpan sidik jari seseorang pelaku tindak pidana sebelum dimasukan kedalam komputer agar tersimpan kedalam database.

Lebih lanjut lagi bagaimana penggunaan sidik jari bisa mendukung suatu proses pembuktian, menurut wawancara dengan Chairil Anwar Tim Identifikasi Sidik Jari Polda Jambi beliau mengatakan bahwa:

Dicontohkan pada sebuah kasus pembunuhan di sebuah rumah, maka rumah itu akan diolah tempat kejadian perkara apakah ada meninggalkan sidik jari atau tidak, andai kata ada meninggalkan sidik jari, maka sidik jari itulah yang akan diolah memakai alat, misal sidik jari itu tertinggal di atas meja, maka akan diambil secara manual. 15

Menurut Chairil kekuatan pembuktian dengan sidik jari itu kuat akan tetapi harus ada bukti yang lain, karena pada dasarnya sidik jari itu hanya sebagai pendukung alat bukti. Dan merupakan bukti awal, sidik jari itu tidak bisa berdiri sendiri tanpa ada bukti yang lain, selama ini untuk di wilayah Polda Jambi belum ada kasus yang terungkap hanya dengan menggunakan sidik jari saja, tetap dicari bukti pendukung lain.

Pengembangan sidik jari sebagai bukti bisa dilakukan dengan cara mengembangkan data sidik jari tersebut melalui keterangan ahli dalam dokumentasi kepolisian dengan data sidik jari yang diperoleh di TKP dan hasil pemotretan sidik jari para terdakwa. Kesesuaian antara keterangan petugas pengambil sidik jari, dokumen tentang data sidik jari terdakwa atau para terdakwa, tanggapan terdakwa terhadap keterangan saksi ahli dan saksi petugas pengambil sidik jari di tempat kejadian perkara tersebut, termasuk alat bukti yang dinamakan petunjuk.

Para penyidik pasti akan terus melakukan penyidikan terhadap suatu kasus pidana, apabila telah ditemukan sidik jari pada barang yang diduga digunakan untuk melakukan tindak pidana maka pihak penyidik akan melakukan pengolahan pada sidik

13 Wawancara dengan Ibrahim, Kanit Ditreskrimum Polda Jambi, Tanggal 16 Januari 2020. Pukul 09.00 WIB.

14 Wawancara dengan Muzammil, Tim Identifikasi Sidik Jari Polda Jambi, Tanggal 16 Januari 2020, Pukul 09.30 WIB.

15 Wawancara dengan Chairil Anwar Tim Identifikasi Sidik Jari Polda Jambi, Tanggal 16 Januari 2020, Pukul 11.30 WIB 
jari tersebut, berdasarkan wawancara dengan penyidik Ditreskrimum Polda Jambi Bapak Ambarita beliau mengatakan bahwa:

Pada saat olah TKP setiap penyidik pasti akan memeriksa dan menggeledah tempat tersebut, dan akan mengamankan bukti-bukti yang ada pada tempat tersebut, kemudian penyidik akan mencari apakah ada sidik jari yang tertinggal ditempat tersebut, bila ditemukan sidik jari maka penyidik akan melihat terlebih dahulu apakah sidik jari tersebut bisa langsung di ambil atau harus menggunakan serbuk dan alat-alat untuk mengambil sidik jari tersebut, apabila sidik jari tersebut menempel pada suatu benda seperti gelas atau meja kaca, maka barang tersebut akan segera dimasukan kedalam kantong plastik lalu diamankan setelah pencarian selesai maka para penyidik akan segera mengolah dan merumuskan sidik jari tersebut, setelah berhasil dirumuskan maka nanti akan terlihat identitas dari pemilik sidik jari tersebut, barulah para penyidik akan mencari orang yang ada pada identitas tersebut. ${ }^{16}$

Pengambilan sidik jari ini sendiri dilakukan dengan menggunakan serbuk yang mengandung magnet pada benda atau alat yang tersangkut pada tindak pidana, kemudian diatas serbuk itu kita tempel plastik khusus untuk mengangkat sidik jari, lalu setelah itu maka akan terlihat dengan jelas sidik jari yang ada pada benda yang tersangkut pada tindak pidana, setelah itu barulah kita cocokan dengan sidik jari orang yang dicurigai.

Menurut wawancara dengan Chairil beliau mengatakan:

Misal pada kasus pencurian disebuah rumah kosong dan tidak ada saksi yang melihat lalu setelah digeledah, maka ditemukan sidik jari, lalu diambil dan diolah sidik jari tersebut, nah ketika diketahui sudah siapa pemilik sidik jari itu, para penyidik tetap akan mencari bukti yang lain yang hilang dirumah tersebut, lalu merekan akan melakukan pencarian terhadap pemilik sidik jari tersebut apabila sudah ketemu dan ternyata barang yang hilang dirumah tesebut juga ada pada pelaku maka penyidik akan mencocokan sidik jari yang kita temui dirumah tersebut dengan sidik jari pada pelaku, bila hasilnya cocok maka kemungkinan dialah pelakunya, akan tetapi penyidik tidak bisa langsung menyimpulkan bahwa memang benar dia pelakunya, tetap akan mencari bukti lain, karena memang sidik jari itu salah satu bukti petunjuk untuk membuat terang suatu tindak pidana. ${ }^{17}$

Jadi pada intinya penggunaan sidik jari ini sangat bisa mendukung proses pembuktian perkara pidana, karena keakuratan sidik jari ini sendiri sangat paten, tidak ada yang bisa menyangkal apabila sudah ditemukannya sidik jari, dibandingkan dengan alat bukti yang lain maka sidik jari ini merupakan yang paling efektif.

Dengan ditemukannya sidik jari pada suatu perkara pidana maka sudah menjadi titik terang kasus tersebut, dan tahu langkah apa yang selanjutnya di ambil yaitu dengan mencari pelaku yang ada pada sidik jari tersebut. Sedangkan dibanding dengan bukti-bukti yang lain yang juga menunjukan benar tidaknya kejahatan tersebut, apabila benar telah terjadi kejahatan, maka baru dicari pelaku dari tindak pidana

16 Wawancara Dengan Ambarita Penyidik Identifikasi Sidik Jari Polda Jambi, Tanggal 16 Januari 2020, Pukul 11.30 WIB.

17 Wawancara dengan Chairil Tim Identifikasi Sidik Jari Polda Jambi, Tanggal 16 Januari 2020, Pukul 11.50 WIB. 
tersebut dan akan memakan waktu ketimbang dengan mencari menggunakan sidik jari.

\section{B. Efektivitas Sidik Jari Sebagai Pendukung Alat Bukti Dalam Proses Penyidikan Perkara Pidana di Polda Jambi}

Berdasarkan 5 kasus tindak pidana yang terjadi di Jambi ini dan penyidikan menggunakan sidik jari sebagai petunjuk awal, disini terlihat bahwa sidik jari efektif untuk digunakan, terlihat dari 5 kasus tersebut dengan mudahnya para penyidik mencari para tersangka dan tidak memakan waktu yang lama.

Berbicara tentang efektivitas sendiri, efektivitas memiliki arti bahwa ukuran suatu keadaan yang menunjukan taraf tercapainya suatu tujuan atau suatu usaha, dikategorikan efektif apabila usaha itu mencapai tujuan atau secara ideal efektifitas dinyatakan dengan ukuran-ukuran yang akan pasti.

Menurut Hans kelsen Jika Berbicara tentang efektivitas hukum, dibicarakan pula tentang Validitas hukum. Validitas hukum berarti bahwa norma-norma hukum itu mengikat, bahwa orang harus berbuat sesuai dengan yang diharuskan oleh normanorma hukum, bahwa orang harus mematuhi dan menerapkan norma-norma hukum. Efektifitas hukum berarti bahwa orang benar-benar berbuat sesuai dengan normanorma hukum sebagaimana mereka harus berbuat, bahwa norma-norma itu benarbenar diterapkan dan dipatuhi.

Sidik jari ini memiliki efektivitas dalam proses penyidikan suatu perkara pidana, apakah sudah efektif atau belum penggunaan sidik jari ini.

Menurut wawancara yang dilakukan dengan Ibrahim beliau mengatakan bahwa "Pengambilan sidik jari itu sebentar tidak memakan waktu, apalagi di Polda Jambi sendiri sudah memiliki alat digital AK-23 yang berisi printer, kamera, live scan, e-ktp reader, dan scanner dokumen, itu tidak sampai lima menit akan terbaca semuanya."18 Lalu Ibrahim juga menambahkan bahwa: "Yang mempunyai alat-alat lengkap seperti ini hanya di Polda saja, di Polres dan Polsek juga mempunyai alat seperti ini tetapi tidak selengkap alat yang ada di Polda, jadi tetap semua urusan tentang sidik jari dialihkan ke Polda, alat ini langsung dikirim dari pusat INAFIS Mabes Polri di Jakarta."19

INAFIS ini merupakan kepanjangan dari Indonesia Automatic Finger Print Identification System yang merupakan olah tempat kejadian perkara dalam satuan reskrim guna memproses pengungkapan suatu tindak pidana melalui kegiatan identifikasi yang disebut INAFIS ini.

Di Polda sendiri alat-alat untuk mengolah sidik jari sangat lengkap, mereka mempunyai dua alat yang kerjanya sangat cepat yaitu Mambis dan Inafis Portable system. Masing-masing alat itu tentunya memiliki kekurangan dan kelebihan masingmasing, untuk alat mambis sendiri dia mempunyai dua sisi pada alatnya, yang satu untuk pengambilan sidik jari dan yang satu nya lagi untuk retina mata, tetapi alat ini hanya untuk pengambilan sidik jari yang masih ada jarinya seperti mayat, nah untuk pengambilan sidik jarinya tinggal menempalkan jari mayat tersebut pada mambis ini

18 Wawancara dengan Ibrahim, Kanit Identifikasi Polda Jambi, Tanggal 16 Januari 2020, Pukul 10.00 WIB.

19 Wawancara dengan Ibrahim, Kanit Identifikasi Polda Jambi, Tanggal 16 Januari 2020, Pukul 10.00 WIB. 
maka akan terlihat langsung identitas mayat tersebut, akan tetapi untuk penggunaan retina mata tidak bisa digunakan pada mayat, harus pada orang yang masih hidup.

Menurut wawancara yang dilakukan dengan Muzammil, beliau mengatakan bahwa:

Untuk sekarang mereka memakai alat mambis dan inafis portable system, tapi kalau dulu ketika melakukan pengambilan sidik jari mereka menggunakan serbuk yang mana untuk mengangkatnya nanti menggunakan plastik khusus sidik jari, tetapi untuk sidik jari yang ditinggalkan ditempat kejadian perkara tetap menggunakan serbuk untuk mengangkatnya barulah nanti diolah di kantor, tapi tidak memakan waktu yang lama apabila langsung dikerjakan hari itu juga maka hasilnya tidak sampai dua jam langsung keluar, tetapi kalau dulu harus mengirim dulu sidik jari yang sudah didapat ke palembang karena di Polda Jambi belum mempunyai alat yang lengkap seperti ini. ${ }^{20}$

Pengambilan sidik jari ini sendiri sebenarnya tidak memakan waktu yang lama, dan sangat efektif karena di Polda sendiri alat-alatnya sudah sangat lengkap, untuk menimbulkan sidik jari yang tertinggal tidak bisa menggunakan mambis ataupun inafis portable system, harus dengan pengangkatan atau penguapan, segala macam sidik jari yang terjadi karena tekanan telapak tangan dengan jari-jarinya dapat dibedakan antara:

a. Sidik jari yang mendalam, disebabkan karena tekanan yang dilakukan pada benda yang lunak sifatnya. Tempat-tempat yang kena tekanan tidak dapat bertahan dan terdesak masuk kedalam. Ruang lekuknya lalu berisi bentuk gambar garis-garis papilar jari.

Ruang lekuk yang mengandung gambar garis-garis papilar itu dengan jalan pemotretan dapat diambil gambarnya. Setelah foto ini dibesarkan secukupnya dapat digunakan untuk membandingkan dengan sidik jari dari orang yang disangka.

b. Sidik jari yang menempel, sidik jari ini terbagi lagi menjadi sidik jari sudah nampak terang dan sidik jari belum nampak (latent). Sidik jari yang sudah nampak disebabkan karena perpindahan beberapa zat warna pada benda lain dengan perantara jari-jari. Sidik jari semacam ini dapat lekas terlihat pada semua benda yang bersifat padar. Olah karena sidik jari berwarna maka selain mudah dilihat juga dapat segera di potret. Sidik jari yang belum nampak (latent) sukar sekali untuk diketahui dan dikenal, apalagi ditempat-tempat yang agak gelap. Apabila di suatu tempat yang tidak begitu terang diduga ada sidik jari yang latent, maka hendaknya jendela dan pintu dibuka agar mendapat sinar terang atau dipakai alat penerang lainnya. Benda yang mengandung sidik jari latent jangan dilihat tegak lurus, tetapi agak miring, penerangan senter juga dijatuhkan agak miring, oleh karena dengan cara demikian sinar akan tertahan oleh garis-garis papilar dan menyebabkan bayangan-bayangan, sehingga sidik jari menjadi dapat dilihat dan juga dipotret. ${ }^{21}$

Ada dua cara kerja untuk menimbulkan sidik jari:

1. Cara mekanis, disini sidik jari ditaburi dengan serbuk berwarna yang kering lalu dihaluskan hingga rata, warna serbuk harus kontras dengan warna benda dimana sidik jari itu menempel.

20 Wawancara dengan Muzammil, Tim Identifikasi Polda Jambi, Tanggal 16 Januari 2020, Pukul 10.55 WIB

21 R.Soesilo, Ilmu Penyidikan Kejahatan, Karya Nusantara, Bandung, 1989, hlm.124. 
Menurut wawancara dengan Muzzamil, mengatakan bahwa: "Pengambilan sidik jari melalui serbuk, serbuk nya pun ada beberapa warna sesuai dengan dimana sidik jari itu menempel, misal pada benda yang terang mereka menggunakan serbuk warna hitam, lalu pada benda yang gelap menggunakan serbuk yang putih." 22

Cara menaburkan serbuknya tidak boleh sembarangan, kalau kebanyakan serbuk yang ditabur, maka garis papilar sidik jari akan tertutup, sehingga sidiknya tidak akan nampak, malah merusak gambarnya. Serbuk-serbuk yang biasa dipakai adalah:

a. Serbuk alumunium: berwarna putih metalik, dapat digunakan pada benda berwarna hitam atau putih.

b. Serbuk air raksa: berwarna kelabu, biasa dipakai untuk sidik jari yang terdapat gelas, piring, benda dari perak.

c. Serbuk arang dan jelaga: dipakai untuk sidik jari latent yang ada diatas kertas yang licin permukaannya serta mengkilat keputih-putihan. ${ }^{23}$

Sidik jari latent yang sudah ditimbulkan gambarkannya dengan serbuk, maka akan diangkat/dipindahkan dengan memakai foli, foli ini terbuat dari bahan bersifat menarik. Permukaan foli yang menarik itu dilekatkan pada sidik jari latent yang sudah dibuat terang gambarnya, sehingga serbuk yang terdapat pada gambar ditarik oleh permukaan, agar sidik jari yang sudah ditarik oleh foli itu tidak rusak maka harus segera ditutup dengan lapisan mika yang tipis.

2. Cara kimia, biasa digunakan pada sidik jari yang tertinggal pada benda benda yang terbuat dari kertas atau kayu yang tidak dapat dikerjakan dengan serbuk, dengan pemakaian yodium, perak nitrat.

Untuk mengambik sidik jari pelaku tindak pidana yang ditangkap tidak dengan sidik jari maka petugas identifikasi harus menyiapkan stamping kit berupa:

1. Kartu AK-23

2. Kartu identitas sidik jari (AK-24)

3. Tinta khusus daktiloscopy sidik jari

4. Roller (penggiling tinta)

5. Magnifer / loop (kaca pembesar)

Setelah semua selesai maka yang harus di lakukan petugas yaitu:

1. Petugas identifikasi melakukan perumusan sidik jari

2. Menyimpan kartu AK-23 kedalam bilik kabinet

3. Memberikan kepada yang bersangkutan / pemohon kartu identitas sidik jari AK-24 yang berlaku seumur hidup

4. Menyerahkan kartu AK-23 ke fungsi Ditintelkam

Sidik jari yang ada pada suatu tempat itu bertahan lama asal tidak ada yang merusaknya, maka pada saat olah tempat kejadian perkara para penyidik pasti akan segera mengamankan daerah disekitar tempat kejadian perkara, menurut

22 Wawancara dengan Muzammil, Tim Identitifkasi Polda Jambi, Tanggal 16 Januari 2020, Pukul 11.55 WIB.

23 R.Soesilo, Loc. Cit. 
Muzammil kalaupun diatas sidik jari itu ada debu bisa dibersihkan debunya, maka akan terlihat lagi bekas sidik jari tersebut.

Untuk di Polda Jambi ini sendiri efektivitas sidik jari dalam mendukung proses penyidikan perkara pidana sudah terbilang efektif dilihat dari 5 kasus yang ditangani semua menggunakan sidik jari sebagai pembuktian awal karena didukungnya oleh alat-alat yang lengkap dan canggih serta anggota kepolisian dibagian identifikasi ini cukup banyak, jadi tidak ada kendala untuk di Polda Jambi ini.

Memang untuk kasus yang terungkap hanya menggunakan sidik jari belum pernah ada, akan tetapi setiap tindak pidana yang terjadi pasti diambil sidik jarinya dan menurut Chairil anwar:

Suatu tindak pidana biasanya tidak ada yang tidak meninggalkan bukti, mungkin memang ada satu atau dua, tapi ya namanya Allah itu adil ada saja cara yang ditunjukan-NYA mungkin memang tidak dalam waktu yang cepat bisa satu tahun, 2 tahun bahkan lebih, ada sebuah kasus dulu dibatanghari itu baru empat tahun baru terungkap karena pelakunya melarikan diri, dan itupun terungkap bukan melalui sidik jari, tetapi seseorang yang melihat pembunuhan yang terjadi. ${ }^{24}$

Dengan adanya alat bukti sidik jari ini menunjukkan bahwa kepolisian semakin meningkatkan sarana yang dimilikinya, dengan mendukung sumber daya manusia dari kepolisian. Adapun peran sidik jari meliputi:

1. Aspek keamanan, aspek keamanan disini meliputi:

a. Membuktikan identitas tersangka

Karena tidak ada orang yang memiliki sidik jari yang sama di dunia ini, sekalipun orang itu kembar, inilah yang menjadikan sidik jari memiliki tingkat keakuratan yang tinggi karena hanya dengan mengambil sidik jari orang tersebut maka akan terlihat identitas orang itu.

b. Sebagai catatan kriminal seseorang

Sesuai dengan Pasal 13 Undang-undang Kepolisian no.2 tahun 2002 tahun 2002 tentang Kepolisian Negara Republik Indonesia, Polri memiliki peran dalam mendata statistik kriminal yang terjadi dan mengusahakan pelaku yang pernah melakukan kejahatan tidak mengulangi lagi perbuatannya. Dalam hal ini, dengan memanfaatkan alat bukti sidik jari Polri dapat membuat data base tentang kejahatan, yaitu dengan mencatat setiap pelaku kejahatan yang melakukan suatu tindak pidana dan mengambil sidik jarinya. Untuk mendapatkan hal tersebut di atas Polri menggunakan suatu alat yang disebut AidedAutomated Finger print Identification System (CAAFIS) yang digunakan untuk menemukan catatan kriminal seseorang, dalam bentuk tertulis dituangkan di kertas AK-23.

24 Wawancara dengan Chairil Anwar, Tim Identitifkasi Polda Jambi, Tanggal 16 Januari 2020, Pukul 12.15 WIB 
c. Untuk mencari DPO

Dengan melihat pada database pelaku kejahatan, unit identifikasi sidik jari dan penyidik dapat mengetahui bahwa pelaku tersebut pernah mereka proses pada kasus sebelumnya, dengan melihat pada file yang ada di data base. ${ }^{25}$

\section{SIMPULAN}

Penggunaan sidik jari bisa mendukung proses pembuktian alat bukti dalam penyidikan perkara pidana karena sidik jari itu sifatnya yang sangat akurat, tidak ada sidik jari orang yang sama di dunia ini, dan dengan penggunaan sidik jari ini, maka proses penyidikan bisa lebih mudah dibanding dengan alat bukti lain, apabila sudah ditemukan sidik jari sebagai barang bukti awal, maka penyidik tinggal mengolah sidik jari tersebut dan akan terlihat langsung identitas pemilik sidik jari tersebut, lalu penyidik tinggal mencari orang yang sudah diketahui identitasnya itu yang di duga sebagai pelaku tindak pidana, sedangkan apabila dengan bukti lain, apabila telah ditemukan bukti tersebut, maka penyidik harus mencari lagi siapa pelakunya tanpa tahu identitas orang tersebut, dan itu lebih memakan waktu, penggunaan sidik jari ini sendiri untuk di Polda Jambi tidak begitu banyak perkara yang menggunakan sidik jari seperti yang terlihat pada tabel jumlah kasus perkara pidana yang terjadi dari tahun 2016 hingga 2019 hanya ada 5 kasus yang menggunakan sidik jari sebagai pembuktian awal.

Untuk efektivitasnya sendiri, untuk Polda Jambi sudah sangat efektif terlihat dari 5 kasus yang terjadi semuanya terungkap dengan menggunakan sidik jari sebagai petunjuk awal karena didukung alat-alat yang canggih yang mana alat-alat tersebut langsung di kirim dari INAFIS pusat di Jakarta, sehingga untuk mengolah sidik jari tersebut tidak memakan waktu yang lama.

\section{DAFTAR PUSTAKA}

\section{Dokumen Hukum}

Republik Indonesia, Undang-Undang tentang Kitab Undang-Undang Hukum Acara Pidana, UU NO. 8 Tahun 1981.

Republik Indonesia. Undang-undang Kepolisian, No. 22 Tahun 2002.

\section{Buku}

Abdussalam, H.R. Buku Pintar Forensik (Pembuktian Ilmiah). Cet. 5. Jakarta: PTIK Press. 2014.

Asis, Abd dan Sofyan Andi Muhammad. Hukum Acara Pidana Suatu Pengantar. Jakarta: Kencana. 2014.

Atmadja, Dewa Gede dan Budiartha, I Nyoman Putu. Teori Teori Hukum. Malang: Setara Press. 2018.

Fuady, Munir. Teori Hukum Pembuktian. Bandng: PT. Citra Aditya Bakti. 2006.

Gumilang, A. Kriminalistik Pengetahuan Tentang Teknik dan Taktik Penyidikan. Cet. 1. Bandung: Angkasa. 1991.

25 R.Soesilo, Loc. Cit. 
Hamzah, Andi. Hukum Acara Pidana Indonesia. Cet. 8. Jakarta: Sinar Grafika. 2014.

Harahap, Yahya. Pembahasan Permasalahan dan Penerapan KUHAP: Pemeriksaan Sidang Pengadilan, Banding, Kasasi, dan Peninjauan Kembali. Cet. 8. Jakarta: Sinar Grafika. 2006.

Lamintang, P.A.F. Dasar-dasar Hukum Pidana Indonesia. Jakarta: Sinar Grafika. 2019.

Nasution, Bahder Johan. Metode Penelitian Hukum. Cet. 2. Bandung: Mandar Maju. 2016.

Soesilo, R. Kriminalistik (Ilmu Penyidikan Kejahatan). Bandung: PT. Karya Nusantara. 1989.

Takariawan, Agus. Hukum Pembuktian Dalam Perkara Pidana di Indonesia. Cet. 1. Bandung: Pustaka Reka Cipta. 2019.

\section{Jurnal:}

Arthadana, Made Gede, "Peran Sidik Jari Dalam Mengungkap Pelaku Tindak Pidana di Polda Bali", Jurnal Magister Hukum Udayana (Udayana Master Law Journal), [S.l.], v. 4, n. 4, dec. 2015. ISSN 2502-3101. https://ojs.unud.ac.id/index.php/jmhu/article/view/18749

Hafrida, "Kebijakan Hukum Pidana terhadap Pengguna Narkotika sebagai Korban Bukan Pelaku Tindak Pidana: Studi Lapangan Daerah Jambi," Padjadjaran Journal Of Law, Vol 1 no. 3, 2016, https://scholar.google.co.id/citations?user=xT8MpbIAAAAJ\&hl=id\#d=gs_m d_cita-d\&u=\%2Fcitations\%3Fview_op\%3Dview_citation\%26hl\%3Did\% 26user\%3DxT8MpbIAAAAJ\%26citation_for_view\%3DxT8MpbIAAAAJ\%3AM 3NEmzRMIkIC\%26tzom\%3D-420

Hafrida, "Perekaman Proses Persidangan Pada Pengadilan Negri Di Tinjau dari Aspek Hukum Acara Pidana," Jurnal Ilmu Hukum, Vol. 5, 2014, https://scholar.google.co.id/citations?user=xT8MpbIAAAAJ\&hl=id\#d=gs_m d_cita-d\&u=\%2Fcitations\%3Fview_op\%3Dview_citation\%26hl\%3Did \%26user\%3DxT8MpbIAAAAJ\%26citation_for_view\%3DxT8MpbIAAAAJ\%3 ANMxIlDl6LWMC\%26tzom\%3D-420

Lasmadi, Sahuri, "Pengaturan Alat Bukti Dalam Tindak Pidana Dunia Maya", Jurnal Ilmu Hukum Jambi, Vol. https://www.neliti.com/publications/43274/pengaturan-alat-bukti-dalamtindak-pidana-dunia-maya\#cite

Monita, Yulia, Wahyudhi, Dheni, "Peranan Dokter Forensik Dalam Pembuktian Perkara Pidana", Jurnal Ilmu Hukum,Vol 6, 2013, https://scholar.google.co.id/citations?user=878U4XEAAAAJ\&hl=id\#d=gs_m d_cita-d\&u=\%2Fcitations\%3Fview_op\%3Dview_citation\%26hl\%3Did\%26 user\%3D878U4XEAAAAJ\%26citation_for_view\%3D878U4XEAAAAJ\%3Au5 HHmVD_u08C\%26tzom\%3D-420

Nawawi, Kabib, "Progresifitas Polisi, Menuju Polisi Profesional", Inovatif Jurnal Ilmu Hukum, Vol. $\quad 2$ 2 Tahun 2010, https://onlinejournal.unja.ac.id/index.php/jimih/article/view/202

Sari, Meli Indah, \& Hafrida, H. (2020),"Penerapan Pidana Penjara Sebagai Pengganti Pidana Denda dalam Putusan Perkara Tindak Pidana Narkotika", PAMPAS: Journal of Criminal Law, 1(1), 38-53. Retrieved from https://www.onlinejournal.unja.ac.id/Pampas/article/view/8260 
Subaidi, "Keabsahan Sidik Jari Sebagai Alat Bukti Dalam Tindak Pidana Perspektif Hukum", Cendekia Jurnal Studi Keislaman, Vol. 2, No. 2, Tahun 2018, http://ejurnal.staiha.ac.id/index.php/cendekia/article/view/31

\section{Website}

Graze, Elizabeth, Dasar Pemberat Pidana, Academia.edu, Diakses pada hari Jumat Tanggal 22 November 2019, Pukul 20.07 WIB.

https://id.wikipedia.org/wiki/Sidik_jari, Diakses pada hari Jumat tanggal 25 oktober 2019, Pukul 11.11 WIB. 